\section{Paweł Rytel-Andrianik}

Università della Santa Croce, Roma

x.rytel@gmail.com

DOI: http://dx.doi.org/10.12775/BPTh.2016.006

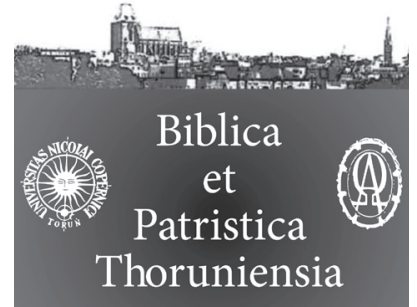

9 (2016) 1: 119-132

ISSN (print) 1689-5150

ISSN (online) 2450-7059

\title{
The Gospel According to Isaiah. A Textual Analysis of Mk 1:1
}

\section{Ewangelia według Izajasza. Analiza tekstualna Mk 1,1}

\begin{abstract}
Detailed linguistic study shows that it is not improbable that Mk 1:1-2a should not be divided by a full stop, but rather by a comma. This is of crucial significance for the whole Gospel of Mark, because this opening phrase could be translated as: "The beginning of the Gospel of Jesus Christ, the Son of God, as it is written in Isaiah the prophet...". Moreover, there are good reasons to suggest that the idea of $\in \dot{v} \alpha \gamma \gamma \gamma^{\prime} \lambda\llcorner\mathrm{L}$ as a good news concerning Jesus Christ "as it is written in Isaiah the prophet" present in Mk 1:2a can be understood in the light of Rm 1:1-4 and vice versa.
\end{abstract}

Streszczenie. Szczegółowe stadium lingwistyczne pokazuje, że nie jest wykluczone, iż wersety Mk 1,1-2a powinny być rozdzielone nie kropką, lecz raczej przecinkiem. To ma kluczowe znaczenie dla całej ewangelii Marka, ponieważ pierwsze zdanie może być przetłumaczone: "Początek Ewangelii Jezusa Chrystusa, Syna Bożego, jak jest na-

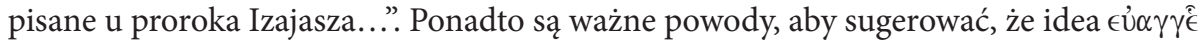
' $\lambda$ ıov jako dobrej nowiny o Jezusie Chrystusie “jak jest napisane u proroka Izajasza...", obecna w Mk 1,2a może być rozumiana w świetle Rz 1,1-4 i vice versa.

Keywords: Gospel; Isaiah; Mark; Letter to the Romans; biblical codices.

Słowa kluczowe: Ewangelia; Izajasz; Marek; List do Rzymian; kodeksy biblijne. 
T $\mathrm{t}$ is perhaps surprising that Isaiah is the only OT author mentioned by name in Mark's Gospel $(1: 2 ; 7: 6)$. True enough, citations from other books are made, however, this directly attributed citation is made at the very beginning of his Gospel, and holds a specific significance, which will later be explored. Indeed, it can be argued that a good knowledge of Second Isaiah is indispensable to understanding "First Mark," if not the whole Gospel, starting even with the term $\epsilon \dot{v} \alpha \gamma \gamma^{\prime} \lambda$ เov.

From textual point of view the beginning of Mark's Gospel is quite problematic. ${ }^{1}$ The reading viô $\theta \in$ Gô is omitted by some important witnesses $\left(\aleph^{*} \Theta 28.530582^{*} 820^{*}\right)^{2}$; it is found, however, in other ancient witnesses

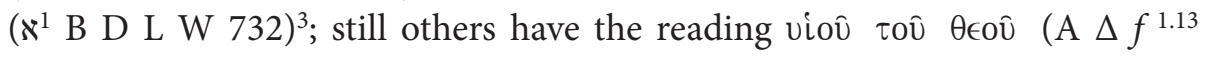

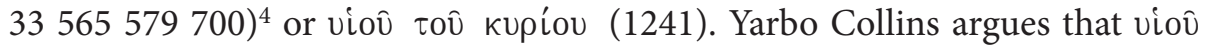
$\theta \in O \hat{v}$ is a secondary addition "because an accidental omission in the opening words of a work is unlikely." Indeed, it was not unknown to expand titles or quasi-titles of books in such a manner (cf. Rev 1:1), ${ }^{6}$ however, this omission could rather occur due to possible oversight in copying, occasioned by the similarity of the endings of the unusual cumulation of the nomina sacra: APXHTOYEYАГГЕ $\Lambda$ IOYIYXYYY[TOY] $\Theta Y{ }^{7}$ In fact, some codices have been corrected at this point with the full nomina sacra abbreviation, among them $\aleph^{1}$. It has been claimed that here are several instances in which $\aleph$ breaks up chains of genitives ending in ov̂, as in this case (cf. e.g., Acts 28:31; Col 2:2; Heb $12: 2$; Rev $12: 14 ; 15: 7 ; 22: 1$ ), showing that there is the possibility of accidental scribal omission in Mk 1:1. ${ }^{8}$ Moreover, this homoioteleuton at the beginning of a work was unusual. ${ }^{9}$ In addition, the identification of Jesus as "Son of God," sometimes thought to be a later addition at this juncture, is not al-

1 This are the references for textual critical analysis of this passage: C. Tischendorf, Novum Testamentum Graece, in loco; $\mathrm{NA}^{28}$, in loco; R. J. Swanson, New Testament Greek Manuscripts, in loco; A. Ammassari, Bezae Codex Cantabrigiensis, in loco.

2 Cf. the same in 2211, $102114361555^{\star} 169224302533 \mathrm{syr}^{(\mathrm{pal})} \mathrm{co}^{\mathrm{sams}} \mathrm{arm}^{\mathrm{mss}}$ Ir $^{\mathrm{pt}}$. Wit-

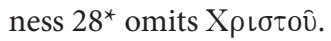

3 Cf. the same in 16022427 latt sy co.

4 Cf. the same in 892107113421424 Byz syp.h.

5 A. Yarbro Collins, Mark, 130; Cf. Idem, “Establishing the text: Mark 1:1," 111-127; P. M. Head, “A Text-Critical Study of Mark 1:1," NTS 37 (1991) 621-629.

6 B.M. Metzger, The Text of the New Testament [ $3 \mathrm{r}^{\mathrm{d}}$ ed.], in loco.

7 C.H. Turner, "Markan Usage," 150; R.A. Guelich, Mark 1-8:26, 6; M. Buscemi, "Critica textus di Mc 1," 73-74; W. Willker, A Textual Commentary on the Greek Gospels, 5-6.

8 W. Willker, A Textual Commentary on the Greek Gospels, 6.

9 J. Slomp, "Are the words 'Son of God' in Mk 1:1 original?," 148; Cf. A. Globe, “The Caesarean Omission of the Phrase 'Son of God' in Mark 1.1," HTR 75 (1982) 209-218. 
ien to Mark's Gospel (cf. Mk 3:11; 5:7; 15:39; $\left(8: 29\right.$ ? $\left.^{10}\right)$ ) and so the likelihood of a later insertion is diminished. ${ }^{11}$ In Mk 1:2a some sources have reading $\omega$ instead of $\kappa \alpha \theta \omega \dot{\varsigma}$, which could be understood to be a replacement for $\kappa \alpha \theta \omega \dot{\omega}{ }^{12}$

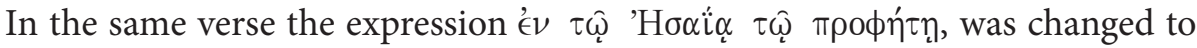

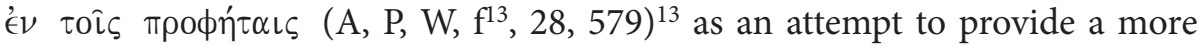
comprehensive introductory formula to the citation, which does not start with the quote from Isaiah, but rather from Mal 3:1/Ex 20:23.

As far as the meaning of the text is concerned, some scholars have argued for a connection between $\alpha \rho \chi \eta ் ~ i n ~ M k ~ 1: 1 ~ w i t h ~ G e n ~ 1: 1 ~(L X X) ~ a n d ~ J n ~ 1: 1-2 .{ }^{14}$ Nonetheless, the meaning of $\alpha \rho \chi \eta$ depends on the meaning of the qualifying phrase, which in Mk 1:1 is not the same as in these two other passages. ${ }^{15}$ At this point, it is interesting to note that at the commencement of all four Gospels the book of the prophet Isaiah is mentioned and always with the same citation from Is 40:3, which is constantly used in reference to John the Baptist. Therefore, there is rather a question whether Mk 1:1 refers to the beginning of the Gospel of Jesus Christ, as marked by John the Baptist, as it is written in Isaiah the prophet (Is 40:3), or simply to the beginning of a new literary composition? ${ }^{16}$

$10 \times \mathrm{L} 157 \mathrm{pc} \mathrm{r}^{1}$ as well as $\mathrm{W} \mathrm{f}^{13} \mathrm{pc}$ b, sy ${ }^{\mathrm{p}} \mathrm{sa}^{\mathrm{mss}}$. Although a harmonization with Mt 16:16 and $\mathrm{Lk}$ 9:20 is suggested.

11 Cf. description of Jesus as Beloved [or Only] Son (Mk 1:11; 9:7; 12:6), the Son (Mk 13:32), Son of the Blessed One.

12 Cf. A, D, M, U, W, f ${ }^{13}(13,69,124,174,230,346,543,788,826,983,1689,1709$ etc), $28,118,579,1424$.

13 The same in $1342, \mathrm{vg}^{\mathrm{ms}}, \mathrm{Sy}^{\mathrm{h}}, \mathrm{Ir}^{\text {lat }}$. A harmonization with Mk 7:6 is suggested, where

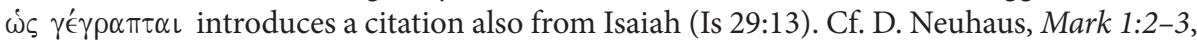
13.

14 Cf. H. Anderson, The Gospel of Mark, 66; D. Neuhaus, Mark 1:2-3, 55-63. See Jewish background of this title in F. Manns, "Il Figlio di Dio (Mc 1,1)," 81-90.

15 For the comparision with the other Gospels see J.M. Gibbs, "Mk. 1,1-15, Mt. 1,1$-4,16$, Lk. 1,1-4,30, Jn. 1,1-51," 154-188.

16 The former solution could be strengthened by the combination of Is 40:3 and Mal 3:1 (cf. Mal 3:22-23) where is an allusion to Elijah, who should come before the arrival of the Messiah and Mk 1:1-3 is an introduction of the figure of John the Baptist. Neverthe-

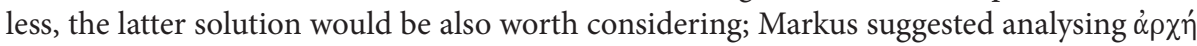
as a temporal nuance. Idem, Mark 1-8, 141; On the basis of Mk 1:1-15 Shenke claimed the preexistence of Jesus Christ. Idem, "Gibt es im Markusevangelium eine Präexistenzchristologie?” 45-71. For other (also non biblical) beginning with ' $\alpha \rho \chi \eta$ cf. BAGD, 111b; For further discussion see J. Kudasiewicz, "Początek ewangelii Jezusa Chrystusa, Syna Boga

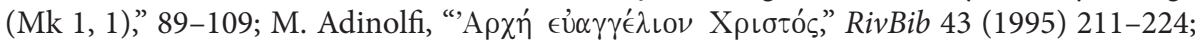
R.S. Poon, “The Beginning of the Gospel,” 103-118. 
Crucial, however, for our understanding of Mk 1:1-3 is the choice of punctuation. In fact, Wikgren identified six categories of interpretation of this passage and Cranfield suggested a list of ten different explanations. ${ }^{17}$ The most important question is whether Mk 1:1 finishes with full stop or a comma. ${ }^{18}$ It seems that the full stop after Mk 1:1, as in $\mathrm{NA}^{28}$ and in many others publications, has to be challenged for various reasons. First of all, $\kappa \alpha \theta \omega$ 's alone never begins a sentence in Mk or elsewhere in NT, except in the unrelated $\kappa \alpha \theta \omega \dot{\varsigma} /$ où

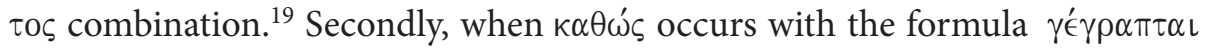
it always refers to the preceding rather than to the succeeding material. ${ }^{20}$ In fact, the expression $\kappa \alpha \theta \dot{\omega} \varsigma \gamma^{\prime} \gamma_{\rho} \alpha \pi \tau \alpha \iota$ is present another two times in the Gospel of Mark and it refers to a particular person, who was mentioned in the preceding phrase, Mk 9:13 - Elijah; 14:21 - The Son of Man. Interestingly, in both cases there is no verbatim citation. Already Spitta noted that $\kappa \alpha \theta \dot{\omega} \varsigma \gamma^{\prime} \epsilon \rho \alpha \pi \tau \alpha \iota$ is "never the introductory clause, but always follows a report of something seen as the fulfillment of a prophetic word." ${ }^{21}$ It seems that, similarly, Mk 1:2a refers to the previous verse.

In such a reading, the subordinate clause seems to lack a main clause, since Mk 1:1 is without a finite verb. There is no exact analogy to Mk 1:1-2b in other biblical books, but it is worth noticing that the anarthrous headings open the Gospel of Matthew and Book of Revelation, and are common in the OT (cf. Prov, Eccl, Cant) in particular for the prophetic books (cf. Is, Jer, Ho, Joel, Am, Ob, Nah, Hab, Zaph, Zc, Ml). In the LXX all of these headings, except those for Jeremiah and Habakkuk characterize the following work by an anar-

17 A. Wikgren, “АРХН TOY ЕYАГГЕАIOY,” JBL 61 (1942) 11-20; C.E.B. Cranfield, The Gospel According to Saint Mark, 34-35.

18 For the variation in translation see L. de Santis, "Mc 1,1. Studio di traduzione," Angelicum 69 (1992) 175-192.

19 V. Taylor, The Gospel According to St Mark, 153; H. Anderson, The Gospel of Mark, 67-68; E. Haenchen, Der Weg Jesu, 39; R.A. Guelich, Mark 1-8:26, 6; R. E. Watts, Isaiah's new Exodus and Mark, 55-56.

20 C.H. Turner, "Markan Usage," 150; Arnold G., "Mk 1:1 und Eröffnungswendungen in griechischen und lateinischen Schriften," 123-124; C.E.B. Cranfield, The Gospel According to Saint Mark, 35; W. Feneberg, Der Markusprolog, 186-187; R.A. Guelich, Mark 1-8:26, 7; J.K. Elliot, "KA $\Theta \Omega \Sigma$ and $\Omega \Sigma \Pi E P$ in the New Testament," 55-56; J. Marcus, The way of the Lord, 17-18; R.E. Watts, Isaiah's new Exodus and Mark, 55-56; N.C. Croy, "Where the Gospel text begins," 7; In in Lk 11:30 (NA $\left.{ }^{28}\right) \kappa \alpha \theta \omega$ ' is after a full stop. Cf. the constant

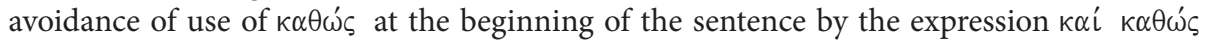
in Lk 17:26; Jn 3:14; 1 Cor 2:9, even though there is no occurrence of $\kappa \alpha \theta \dot{\omega} \varsigma$ $\gamma^{\prime} \gamma \rho \alpha \pi \tau \alpha \mathrm{L}$.

21 F. Spitta, "Der Anfang des Markus-Evangeliums," 306. 
throus noun..$^{22}$ Thus the heading could be an example of ellipse. It seems that Mk 1:1 could be simply influenced by Hebrew or Aramaic syntax, which omits the verb "to be" in present tense. In addition, an ellipse of the verb "to be" is not alien to Marcan Greek. ${ }^{23}$

In recent scholarship on $\mathrm{Mk}$ 1:1-2a, a reference to ancient textual witnesses is often missing. ${ }^{24}$ In fact, the way in which this text was written in ancient codices could provide us with important insights. Some ancient witnesses do not have an incipit (B, W), but those which have it, place it in a similar position: ${ }^{25}$

\author{
Sinaiticus $\left(\aleph^{*}\right)$ \\ ARCHTOUEUAGGELI \\ OUIUCUKAQWSGE \\ GRAPTAIENTWHSA \\ IATWPROFHTH \\ IDOUEGWAPOSTE \\ LWTONAGGELONMOU
}

Alexandrinus (A)

\author{
ARCHTOUEUAGGELIOUIUCUUUTOUQU \\ WSGEGRAPTAIENTOISPROFHTAIS \\ IDOUEGWAPOSTELIWTONAGGELO \\ MOUPROPROSWPOUSOUWSKATA
}

Bezae (D)

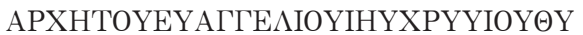

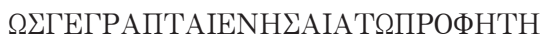

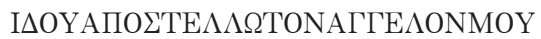

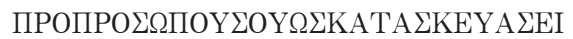

In codices Sinaiticus and Alexandrinus the incipit occurs in the same place, which marks the first segment as vv. 1-2a. The following segment begins with the first citation. ${ }^{26}$ In codex Bezae the incipit is only in the first line and the text of the citations is without incipit on the other line (following the empty space). This demonstrates that $\mathrm{KA} \Theta \Omega \Sigma / \Omega \Sigma$ never forms an incipit in order to start

\footnotetext{
22 R.T. France, The Gospel of Mark, 51.

23 Cf. superb article A. Niccacci, "La narrativa di Mc 1," 59-71; J. Ch. Doudna, The Greek of the Gospel of Mark, 4-5.

24 M.E. Boring, "Mark 1:1-15 and the Beginning of the Gospel," 185-192; J. Zmijewski, "Markinischer 'Prolog' und Täufertradition," 41-62; P.J. Sankey, "Promise and Fulfillment," 3-18; N. C. Croy. "Where the Gospel text begins," 106-127; J.K. Elliott, "Mark 1.1-3. A Later Addition to the Gospel?" 584-588; Guijarro Oporto S., "Why Does the Gospel of Mark Begin as It Does?” 28-38 Guijarro Oporto S., “¿Por qué comienza así el evangelio de Marcos?" 133-151.

25 In the three most important papyruses for the Gospel of Mark (P45, P84, P88) there is physical absence of Mk 1:1ff. Cf. $\mathrm{NA}^{28}$, in loco.

26 Codex Alexandrinus, however sometimes puts randomly an incipit, which seems rather matter of artistic presentation of the texts than the indication of the division of it.
} 
something new, but always is related to that which came before, i.e. Mk 1:1. Moreover, it is very important to notice that in codex Sinaiticus after Mk 1:2a is a dot, which seems to be a sign for a pause used in other places (cf. after Mk 1:2,3 etc). ${ }^{27}$ Also after Mk 1:2a comes a small empty space, a typical sign in Sinaiticus used to indicate a pause (cf. after Mk 1:2,3,4, 6, 7, 10 etc.). It is remarkable that codex Alexandrinus follows the same pattern. There is a dot after v. 2a, which the usual sign to indicate a full stop in this textual witness (cf. after Mk 1:2,3,5,6 (after $\alpha$ u ôे), 6 (at the end of the verse) etc. Similarly, like in Sinaiticus there is an empty space after v. 2 and 3.

It is difficult to judge whether these textual witnesses show the original version of the text, but the repetition of the same incipit in such important sources like $\aleph, \mathrm{A}, \mathrm{D}$ (not in contrast to $\mathrm{B}, \mathrm{W}$ ) has to be taken into consideration, even more so because it agrees with a syntactical analysis of $\kappa \alpha \theta \dot{\omega} \varsigma \gamma^{\prime} \epsilon \rho \alpha \pi \tau \alpha$. Thus, it is not improbable that Mk 1:1-2a should not be divided by a full stop, but rather by a comma. This is of vital significance for the whole Gospel of Mark, because this opening phrase can now be translated as: "The beginning of the Gospel of Jesus Christ, the Son of God, as it is written in Isaiah the prophet..." This leads to the questions about the meaning of the term "Gospel" in Mark, and its use in relation to Old Testament prophecies.

Firstly, what can be made of the Greek term commonly translated as "Gospel”? The Septuagint translates the root בשר as $\epsilon \dot{v} \alpha \gamma \gamma \in \lambda \dot{i} \alpha$, but originally it meant the reward given to a bearer of good news and then later came to refer to a good news itself (often about a victory) and the verb $\epsilon \dot{\omega} \alpha \gamma \gamma \in \lambda i \zeta \omega$ in the OT meant "to announce glad tidings." ${ }^{28}$ Dormeyer suggests that $\epsilon \dot{v} \alpha \gamma \gamma^{\prime}\langle\lambda\llcorner\mathrm{L}$ in Mk 1 describes the literary genre of the work. ${ }^{29}$ Frankemölle and Stuhlmacher argue that the Christian use of Gospel is semantically unique, but it was inspired by the use of the related verb in Deutero-Isaiah. ${ }^{30} \mathrm{~J} . \mathrm{P}$. Dickson claims that the noun and the verb express something that is "news" to the audience. ${ }^{31}$ G. Stanton suggests that imperial use of this term was not the source for Christian use but

27 Two horizontal dots usually were used to indicate a textual variants. Cf. Ch.-B. Amphoux, “Codex Vaticanus B. Les points diacritiques des marges de Marc," JTS 58 (2007) $440-466$.

28 The singular form $\epsilon \dot{\cup} \alpha \gamma \gamma^{\prime} \in \lambda$ เov does not appear in the LXX; For recent scholarship on the term "Gospel" cf. H. Frankemölle, Evangelium; J.P. Dickson, "Gospel and News," 212-230; M. Hengel, Die vier Evangelien und das eine Evangelium von Jesus Christus.

29 D. Dormeyer, "Die Kompositionsmetapher 'Evangelium Jesu Christi, des Sohnes Gottes' Mk 1.1," 452-468.

30 H. Frankemölle, Evangelium, 253-254; P. Stuhlmacher, Das paulinische Evangelium, 286-289.

31 J.P. Dickson, “Gospel and News," 212-230. 
"the background against which distinctively Christian usage was forged and first heard." 32

Indeed, Marxsen even suggested that Mark has introduced the noun

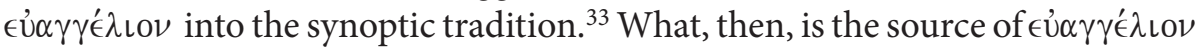
in Mk 1:1? The mention of the name Isaiah at the beginning of the gospel is not enough to claim that it is of Isaianic provenance. In fact, in Isaiah the noun $\epsilon \dot{U} \alpha \gamma \gamma^{\prime} \in \lambda\llcorner O \nu$ is never present as it is in Mark, and in Mark the verb $\epsilon \dot{U} \alpha \gamma \gamma \in \lambda \hat{\imath} \zeta \omega$

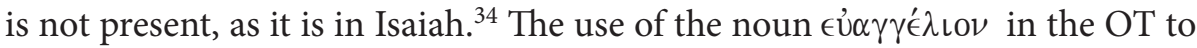
refer to good news about a victory, does not correspond with Markan usage, nor with NT usage in general. ${ }^{35}$ It should be noted, however, that the verb $\epsilon \dot{v} \alpha \gamma \gamma \in \lambda \dot{i} \zeta \omega$ in Isaiah is used only once in a finite form (Is 60:6). The other times it is used as a participle (Is 40:9 twice; Is 52:7 twice) and as an infinitive (Is 61:1). The link between the noun $\epsilon \dot{U} \alpha \gamma \gamma \gamma^{\prime} \lambda\llcorner\mathrm{L} \nu$ and the participle $\epsilon \dot{v} \alpha \gamma \gamma \in \lambda i \zeta \omega$ is quite natural, since the noun and the verb come from the same Hebrew root בשר (cf. 2 Sam 4:10). When we compare the influence of Second Isaiah on Mk $1: 1-13$, it becomes clear that Mark could easily know this verb; for instance Mk 1:3 quotes Is 40:3 but a few verses later in Is 40:9, which he would arguably have known, the participle $\epsilon \dot{v} \alpha \gamma \gamma \in \lambda i \zeta o \nu \tau \epsilon \varsigma$ occurs twice. ${ }^{36}$ Therefore, a certain dependence of Mark on Isaiah in the use of this term can, in fact, be traced.

However, the main concern is not only the provenance of the term but

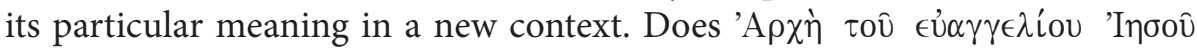

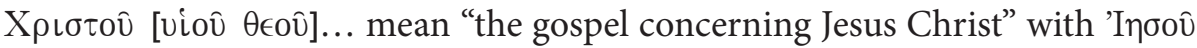
$\mathrm{X} \rho\left\llcorner\sigma \tau o v\right.$ as an objective genitive ${ }^{37}$ or "the gospel proclaimed by Jesus Christ" with an subjective genitive ${ }^{38}$ or is there a double entendre ${ }^{39}$ The latter option poses syntactical difficulty, since one or the other emphasis has to dominate. As Guelich argues the subjective genitive results often from "the misplaced emphasis on 1:14 from which 1:1 has been interpreted rather than interpreting 1:14 in terms of 1:1 with the latter providing the redactional setting for the tra-

32 G.N. Stanton, Jesus and Gospel, 2.

33 W. Marxsen, Der Evangelist Markus, $125 \mathrm{ff}$.

34 E. Hatch - H.A. Redpath (et al.), A Concordance to the Septuagint, 568.

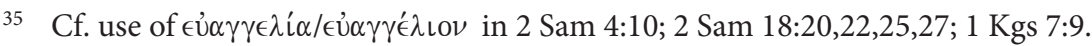

36 Used as participle in Is 40:9 (twice) and 52:7 (twice); as infinitive in Is 61:1.

37 Cf. E. Schweizer, "Die theologishe Leisung des Markus," 30-31; R. Pesch, "Anfang des Evangeliums Jesu Christi," 108-113; R.A. Guelich, Mark 1-8:26, 9.

38 Cf. C.E.B. Cranfield, The Gospel According to Saint Mark, 35-36; G. Dautzenberg, "Die Zeit des Evangeliums, 223-224.

39 R.T. France, The Gospel of Mark, 53; J. Marcus, Mark 1-8, 146-147; S. Haręzga, Jezus i Jego uczniowie, 40. 
ditional reference of the former." 40 The noun, used in the absolute state (typical for Mark against other Synoptics), ${ }^{41}$ refers to a message to be believed (Mk 1:15) or proclaimed (Mk 13:10;14:9), rather than to the act of proclamation, though in the remaining two uses $(\mathrm{Mk} 8: 35 ; 10: 29)$ either sense is possible. It is more appropriate to read Mk 1:1 as an objective genitive, which is a more natural us-

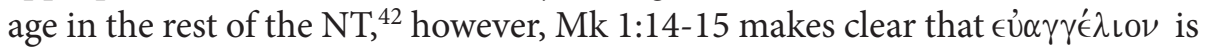
preached by Jesus as well. It also has to be added that the term "gospel" in Mk 1:1 denotes the content rather than the literary type of the book. ${ }^{43}$

If the connection between Mk 1:1 and Mk 1:2a is accepted as well as an objective genitive, a unique quality of the term $\epsilon \dot{v} \alpha \gamma \gamma^{\prime} \lambda^{\prime} \iota$ เov could be introduced.

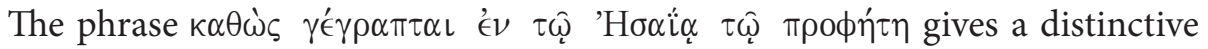
meaning to the very first line of Mark's gospel. The evangelist refers to what is written in Isaiah the prophet as a good news concerning Jesus Christ. ${ }^{44}$

In this case, the resemblance of $\mathrm{Mk} 1: 1-2 \mathrm{a}$ and $\mathrm{Rm} 1: 1-4$ is striking. It seems that there is analogous understanding of the Gospel. Similar syntax of the phrase strengthens this idea:

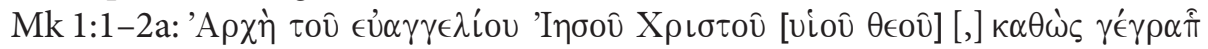

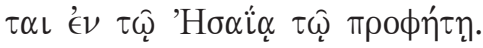

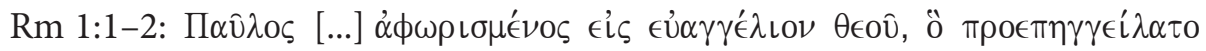

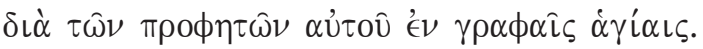

In both cases the subordinated phrase explains the term "gospel," as delivered by Isaiah/prophets and there are various similar expressions, such as:

40 R.A. Guelich, Mark 1-8:26, 9; Cf. Idem, “'The Beginning of the Gospel’ Mark 1:1-15," BR 27 (1982) 5-15.

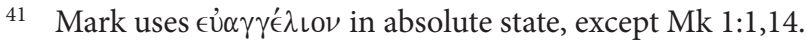

42 Cf. R.T. France, The Gospel of Mark, 53; Though note the contrary i.e. Rm 2:16; 16:25, and denoting the recipients of the gospel Gal 2:7.

43 Cf. R.T. France, The Gospel of Mark, 52-53; J. Schröter, “The Gospel of Mark," 280-

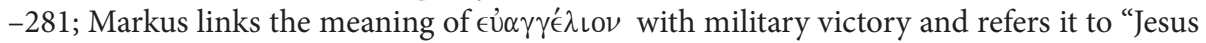
ministry and triumph over demonic forces and their human agents." J. Marcus, Mark 1-8, 146.

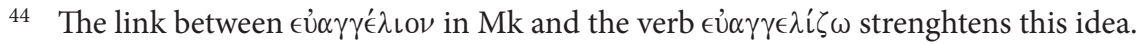


Rm 1

\begin{tabular}{|c|c|c|c|}
\hline & Introduction to the $\mathrm{Go}$ & & Introduction to the letter \\
\hline $\begin{array}{l}\text { v. } 1 \\
\text { (v. } 14)\end{array}$ & $\begin{array}{l}\text { Gospel of Jesus Christ } \\
\text { (Gospel of God) }\end{array}$ & v. 1 & Gospel of God \\
\hline v. 1 & Jesus Christ & $\begin{array}{l}\text { v. } 1 \\
\text { v. } 4\end{array}$ & $\begin{array}{l}\text { Christ Jesus } \\
\text { Jesus Christ }\end{array}$ \\
\hline v. 1 & Son of God & $\begin{array}{l}\text { v. } 3 \\
\text { v. } 4\end{array}$ & $\begin{array}{l}\text { concerning His son (Son of God) } \\
\text { Son of God }\end{array}$ \\
\hline v. 2 & prophet Isaiah & v. 2 & prophets \\
\hline v. 2 & $\begin{array}{l}\text { as it is written } \\
\left(\kappa \alpha \theta \dot{\omega} \varsigma \gamma^{\prime} \gamma \rho \alpha \pi \tau \alpha \iota\right)\end{array}$ & v. 2 & $\begin{array}{l}\text { in the holy scriptures } \\
(\epsilon \nu \quad \gamma \rho \alpha \phi \alpha \hat{i} \varsigma \dot{\alpha} \gamma \dot{i} \alpha \iota \varsigma)\end{array}$ \\
\hline
\end{tabular}

Paul uses the verb $\pi \rho \circ \epsilon \pi \alpha \gamma \gamma^{\prime} \lambda \lambda \lambda \omega$, which occurs only twice in the Greek Bible (cf. 2 Cor 9:5), but only here in a finite form. Its use in the middle form is very significant, but even more its context. The verb $\pi \rho \in \epsilon \alpha \gamma \gamma \gamma^{\prime} \lambda \lambda \omega$ referes to $\epsilon \dot{\cup} \alpha \gamma \gamma^{\prime} \in \lambda\llcorner O \nu$ $\theta \in \mathrm{v}$, which raises the question of whether this is a use of alliteration, typical in Jewish Scripture, as well as an attempt to link the noun with the verb. Moreover, the socio-historical context of the letter to the Romans and the Gospel of Mark can not be overlooked, since their writers belong to similar early Christian circles - both works were written quite early and Mark and Paul quite often refer to Isaiah (cf. Rm 9-10).

There are good reasons to suggest that the idea of $\epsilon \dot{v} \alpha \gamma \gamma^{\prime} \in \lambda\llcorner o \nu$ as a good news concerning Jesus Christ "as it is written in Isaiah the prophet" present in Mk 1:2a can be understood in the light of $\mathrm{Rm} 1: 1-4$ and vice versa. The ancient textual witnesses (i.e., A, D) confirm such syntactical and contextual analysis.

\section{Bibliography}

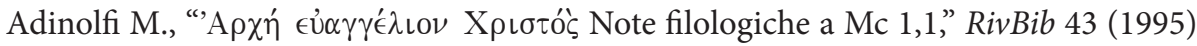
211-224.

Aland, K., Vollständige Konkordanz zum griechischen Neuen Testament, I-II (Berlin - New York: Walter de Gruyter, 1978-1983).

Anderson H., The Gospel of Mark. Based on the Revised Standard Version (New Century Bible Commentary; Grand Rapids MI, London: Eerdmans, Marshall, Morgan \& Scott: 1981).

Arnold G., "Mk 1:1 und Eröffnungswendungen in griechischen und lateinischen Schriften," ZNW 68 (1977) 123-127. 
Beaton R.C., "Isaiah in Matthew’s Gospel," in: M. S. Moyise - M.J.J. Menken (eds), Isaiah in the New Testament (London: T\&T Clark, 2005) 63-78.

Borgen P., Fuglseth K., Skarsten R., The Philo Index. A Complete Greek Word Index to the Writings of Philo of Alexandria (Leiden et al.: Brill et al., 2000).

Boring M.E., "Mark 1:1-15 and the Beginning of the Gospel," in D. Smith (ed.), How Gospels Begin (Semeia 52; Atlanta GA: Scholars Press, 1991) 185-192.

Buscemi M., "Critica textus di Mc 1," in M. Adinolf, P. Kaswalder (eds), Entrarono a Cafarnao (FS V. Ravanelli; SBF A 44; Jerusalem: Franciscan Printing Press, 1997) 73-80.

Catchpole D. R., “The Beginning of Q. A Proposal,” NTS 38 (1992) 205-221.

Catchpole D. R., The Quest for Q (Edinburgh: Clark, 1993).

Cohen M. (ed.), מקראות גדולות הכתר. ספר ישעיהו (Ramat-Gan: Bar Ilan University, 1996).

Cranfield C.E.B., The Gospel According to Saint Mark (Cambridge: Cambridge University Press, 1959).

Croy N.C., "Where the Gospel text begins. A non-theological interpretation of Mk 1:1," NovT 43 (2001) 106-127.

Dautzenberg G., "Die Zeit des Evangeliums. Mk 1,1-15 und die Konzeption des Markusevangeliums," Biblische Zeitschrift 22 (1978) 76-91.

de Santis L., “Mc 1,1. Studio di traduzione," Angelicum 69 (1992) 175-192.

Delorm J., "Evangile et recit. La narration evangelique en Marc," NTS 43 (1997) 367-384 .

Devisch M., "La relation entre l'evangile de Marc et le document Q," in M. Sabbe (ed.), Levangile selon Marc. Tradition et redaction (BETL 34; Leuven: University, Peeters, ${ }^{2}$ 1988) 59-91.

Dickson J.P., "Gospel and News. Eủ $\gamma \gamma \gamma \in \hat{\epsilon} \lambda$ - form Aristophanes to the Apostle Paul," NTS 51 (2005) 212-230.

Donahue J.R., Harrington D.J., The Gospel of Mark (Sacra Pagina 2; Collegeville, Minnesota: The Liturgical Press, 2002).

Dormeyer D., "Die Kompositionsmetapher 'Evangelium Jesu Christi, des Sohnes Gottes' Mk 1.1. Ihre Theologische und literarische Aufgabe in der Jesus Biographiedes Markus," NTS 33 (1987) 452-468.

Doudna J. Ch., The Greek of the Gospel of Mark (JBL Monograph Series, 12; Philadelphia: Society of Biblical Literature and Exegesis, 1961).

Dunderberg I., "Q and the Beginning of Mark," NTS 41 (1995) 501-511.

Elliot J.K., “Mark 1.1-3 - A Later Addition to the Gospel?” NTS 46 (2000) 584-588.

Elliot J.K., "J.K. Elliot, "KA $\Theta \Omega \Sigma$ and $\Omega \Sigma \Pi E P$ in the New Testament," Filologia Neotestamentaria 7 (1991) 55-58.

Elliott J.K., "Mark and the Teaching of Jesus: An Examination of $\Lambda$ ОГО $\Sigma$ and euaggelion", in W.L. Petersen, J.S. Vos, H.J. de Jonge (eds), Sayings of Jesus. Canonical and Non-Canonical. Essays in Honour of Tjitze Baarda (NovTSup 89; Leiden, 1997) 37-45.

Ernst J., Johannes der Taufer. Interpretation - Geschichte - Wirkungsgeschichte (BZNW 53; Berlin: de Gruyter, 1989). 
Evans C.A., To See and not Perceive. Isaiah 6.9-10 in Early Jewish and Christian Interpretation (JSOT 64; Sheffield: JSOT Press 1989).

Feneberg W., Der Markusprolog. Studien zur Formbestimmung des Evangeliums (SANT 36; München: Kösel-Verlag, 1974).

Fitzmyer J.A., “4Q Testimonia and the New Testament,” Theological Studies 18 (1957) 513-537.

France R.T., The Gospel of Mark. A Commentary on the Greek Text (New International Greek Testament Commentary; Grand Rapids, Mich, Carlisle; Eerdmans, Paternoster Press, 2002).

Frankemölle H., Evangelium. Begriff und Gattung. Ein Forschungsbericht (Stuttgarter biblische Beiträge 15; Stuttgart: Verlag Katholisches Bibelwerk, 21994).

Freed E.D., Old Testament Quotations in the Gospel of John (NT.S 11; Leiden: E.J. Brill 1965).

Galbiati G., "Nel deserto preparate la via... (Isaia 40:3, e le sue citazioni)," RicBR 15 (1981) 7-16.

Gibbs J.M., "Mk. 1,1-15, Mt. 1,1-4,16, Lk. 1,1-4,30, Jn. 1,1-51. The Gospel Prologues and their Function," in E. A. Livingstone, Studia Evangelica. Vol.VI (Berlin: Akademie-Verlag, 1973) 154-188.

Guelich R.A., “'The Beginning of the Gospel’ Mark 1:1-15,” BR 27 (1982) 5-15.

Guelich R.A., Mark 1-8:26 (WBC 34A; Dallas, Tex: Word Books, 1989).

Guijarro Oporto S., “PPor qué comienza así el evangelio de Marcos?” in R. Trevijano Etcheverría et al. (eds), Plenitudo temporis. Miscelánea homenaje al Prof. Dr. Ramón Trevijano Etcheverría (Bibliotheca Salmanticensis. Estudios 249; Salamanca: Ediciones Universidad Pontificia de Salamanca, 2002) 133-151 [English translation: "Why Does the Gospel of Mark Begin as It Does?" Biblical Theology Bulletin 33 (2003) 28-38.

Haenchen E., Der Weg Jesu. Eine Erklärung des Markus-Evangeliums und der kanonischen Parallelen (Berlin: Töpelmann, 1966).

Haręzga S., Jezus i Jego uczniowie. Model Chrześcijańskiej formacji w Ewangelii św. Marka (Lublin: Wydawnictwo KUL, 2006).

Hatch E. - Redpath H.A., A Concordance to the Septuagint And the Other Greek Versions of the Old Testament (Including the Apocryphal Books) (Grand Rapids, MI: Baker Books, ${ }^{2}$ 1998).

Head P.M., "A Text-Critical Study of Mark 1:1: 'The Beginning of the Gospel of Jesus Christ," NTS 37 (1991) 621-629.

Hengel M., Die vier Evangelien und das eine Evangelium von Jesus Christus. Studien zu ihrer Sammlung und Entstehung (WUNT 224; Tübingen: Mohr Siebeck, 2008).

Hergesel A.T., Preparate la via del Signore, Is 40:3-5. La sua reinterpretazione giudaica e neotestamentaria con speciale riferimento alla missione di Giovanni Battista (Roma: PUG, 1975).

Kudasiewicz J., "Początek ewangelii Jezusa Chrystusa, Syna Boga (Mk 1, 1)," Roczniki Teologiczno-Kanoniczne 43 (1996) 89-109.

Lambrecht J., "John the Baptist and Jesus in Mark 1.1-15. A Marcan Redaction of Q?" NTS 38 (1992) 357-384. 
Liddell H.G., Scott R., A Greek-English Lexicon. With Supplement (Oxford: Clarendon Press, $\left.{ }^{9} 1989\right)$.

Lincoln A.T., Truth on trial. The Lawsuit Motif in the Fourth Gospel (Peabody, Mass.: Hendrickson Publishers, 2000).

Mack B. L., "Q and the Gospel of Mark. Revising Christian Origins," Semeia 55 (1991) 15-39.

Manns F., "Il Figlio di Dio (Mc 1,1)," in M. Adinolfi, P. Kaswalder (eds), Entrarono a Cafarnao (FS V. Ravanelli; SBF A 44; Jerusalem: Franciscan Printing Press, 1997) 81-90.

Marcus J., The way of the Lord. Christological Exegesis of the Old Testament in the Gospel of Mark (Edinburgh : T\&T Clark, 1993).

Markus J., Mark 1-8 (The Anchor Bible; New York NY et al.: Doubleday, 2000).

Marxsen W., Der Evangelist Markus. Studien zur Redaktionsgeschichte des Evangeliums (FRLANT 49; Göttingen: Vandenhoeck \& Ruprecht, 21956).

Menken M.J.J., Old Testament Quotations in the Fourth Gospel. Studies in Textual Form (CBETh 15; Kampen: Kok Pharos, 1996).

Metzger B.M., The Text of the New Testament. Its Transmission, Corruption, and Restoration (London: Oxford University Press, 31992).

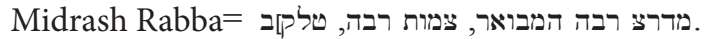

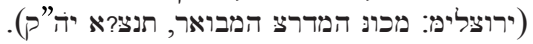

Moyise S., “The Wilderness Quotation in Mark 1.2-3," in R. S. Sugirtharajah (ed.), Wilderness. Essays in Honour of Frances Young (London, New York: Clark, 2005) $78-87$.

Nestle E., "How Does the Gospel of Mark Begin," The Expositor, vol. 4, 10 (1894) 458-460.

Neuhaus D., Mark 1:2-3. An Exegetical Crux (not published SSL dissertation at PBI; Rome 1999; of courtesy of the author).

Niccacci A., "La narrativa di Mc 1," in M. Adinolfi, P. Kaswalder (eds), Entrarono a Cafarnao (FS V. Ravanelli; SBF A 44; Jerusalem: Franciscan Printing Press, 1997) 59-71.

O'Brien K.S., The Use of Scripture in the Markan Passion Narrative (LNTS 384; LondonNew York, NY: Clark, 2010).

Pesch R., "Anfang des Evangeliums Jesu Christi. Eine Studie zum Prolog des Markusevangeliums (Mk 1,1-15), in Idem, Das Markus Evangelium (Darmstadt: Wissenschaftliche Buchgesellschaft, 1979) 311-355.

Poon R.S., “'The Beginning of the Gospel' The Introductory Statement of Mark's Gospel (1:1-3)," Pastoral Journal/Jian Dao 8/13 (1999), 103-118.

Rahlfs A. (ed.), Septuaginta. Psalmi cum odis (Vetus Testamentum graece auctoritate Societatis Göttingensis editum 10; Göttingen: Vandenhoeck \& Ruprecht, ${ }^{3} 1979$ ).

Reim G., Studien zum alttestamentlichen Hintergrund des Johannesevangeliums (SNTSMS 22; Cambridge: Cambridge University, 1974).

Rengstorf K. H. et al. (ed.), A Complete Concordance to Flavius Josephus, II (Leiden: Brill, 1975). 
Robinson J. M., Hoffmann P., Kloppenborg Verbin J. S. (eds), The Critical Edition of Q. Synopsis Including the Gospels of Matthew and Luke, Mark and Thomas with English, German, and French Translations of Q and Thomas (Leuven: Peeters, 2000).

Sankey P.J., "Promise and Fulfillment. Reader-Response to Mk 1.1-15," JNTS 58 (1995) $3-18$.

Schenke L., "Gibt es im Markusevangelium eine Präexistenzchristologie?" ZNW 91 (2000) 45-71.

Schneck R., $\quad$ Isaiah in the Gospel of Mark I-VIII (Bibal Dissertation Series 1; Bogotá: Bibal Press, 1994).

Schröter J., "The Gospel of Mark," in D. E. Aune (ed.), The Blackwell companion to the New Testament (Chichester, Malden, MA: Wiley-Blackwell 2010) 272-295.

Schuchard B.G., Scripture within Scripture. The Interrelationship of Form and Function in the Explicit Old Testament Citations in the Gospel of John (SBLDS 133; Atlanta, GA: Scholars Press 1992).

Shalom P., ישעיה פרקים. מ-10 עם מבוא ופרקים (Tel Aviv-Jerusalem: Am Oved PublishersMagnes Press, 2008).

Sollamo R., Renderings of Hebrew Semiprepositions in the Septuagint (Annales Academiae Scienciarum Fennicae, Dissertationes Humanarum Litterarum 19; Helsinki: Suomalainen Tiedeakatemia, 1979.

Spitta F., "Beiträge zur Erklärung der Synoptiker," ZNW 5 (1904) 303-326.

Stenning J. F., The Targum of Isaiah (Oxford: The Clarendon Press, 1949).

Syx R., "Jesus and the Unclean Spirit. The Literary Relation between Mark and Q in the Beelzebul Controversy," LouvSt 17 (1992) 166-180.

Taylor V., The Gospel According to St Mark (London, New York NY: Macmillan, St Martins Press, 21966).

Telford W.R., Writing on the Gospel of Mark (Guides to Advanced Biblical Research; Blandford Forum: Deo Publishing, 2009).

Tuckett Ch., "Mark and Q", in C. Focant (ed.), The Synoptic Gospels. Source Criticism and the New Literary Criticism (BETL 110; Leuven: University, Peeters, 1993) 149-175.

Turner C.H., "Markan Usage: Notes, Critical and Exegetical, On the Second Gospel," JTS 26 (1925) 145-156.

Turner C.H., "Markan Usage: Notes, Critical and Exegetical, On the Second Gospel," JTS 26 (1925) 145-156.

von Tischendorf C., Novum Testamentum Graece (8th ed.; 3 vols.; Lipsiae: Giesecke \& Devrient, 1869-72).

Watts R.E., Isaiah's new Exodus and Mark (WUNT 88; Tübingen: Mohr Siebeck 1997).

Way-Rider R., "The Lost Beginning of St. Mark's Gospel," in Studia Evangelica (Vol. 7; ed. Elizabeth A. Livingstone; Berlin: Akademie-Verlag, 1982) 553-556.

Wellhausen J., Das Evangelium Marci. Übersetzt und Erklärt (Berlin: Verlag von Georg Reimer, 1903). 
Wevers J.W., Quast U. (ed.), Exodus (Septuaginta. Vetus Testamentum Graecorum Auctoritate Societatis Litterarum Gottingensis editum II,1; Göttingen: Vandenhoeck - Ruprecht, 1991).

Wikgren A., “АРXН TOY ЕYАГГЕАIOY,” JBL 61 (1942) 11-20.

Willker W., A Textual Commentary on the Greek Gospels, Vol. 2: Mark (Bremen, online published, ${ }^{7} 2010$ ).

Yarbro Collins A., "Establishing the text: Mark 1:1," in T. Fornberg et al. (eds), Texts and Contexts. The Function of Biblical Texts in Their Textual Situational Contexts. Essays in Honor of Lars Hartman (Oslo: Scandynavian University Press, 1995) 111-127.

Yarbro Collins A., Mark. A commentary (Hermeneia; Minneapolis MN: Fortress Press, 2007).

Ziegler J. (ed.), Duodecim prophetae (Septuaginta. Vetus Testamentum Graecorum Auctoritate Societatis Litterarum Gottingensis editum XIII; Göttingen: Vandenhoeck - Ruprecht, ${ }^{2}$ 1967).

Ziegler J. (ed.), Isaias (Septuaginta. Vetus Testamentum Graecorum Auctoritate Societatis Litterarum Gottingensis editum XIV; Göttingen: Vandenhoeck - Ruprecht, $\left.{ }^{2} 1967\right)$.

Zmijewski J., "Markinischer 'Prolog' und Täufertradition. Eine Untersuchung zu Mk 1, 1-8," Studnien zum Neuen Testament un seiner Umwelt 18 (1993) 41-62. 